\title{
Growth and mortality patterns in a thinning canopy of post-hurricane regenerating rain forest in eastern Nicaragua (1990-2005)
}

\author{
Javier Ruiz ${ }^{1,2 *}$, John Vandermeer ${ }^{1} \&$ Iñigo Granzow de la Cerda ${ }^{1,3}$ \\ 1. Department of Ecology and Evolutionary Biology, University of Michigan, Ann Arbor, Michigan, USA. \\ 2. Programa Cientifico Complementario. Managua, Nicaragua. www.javierruizperez.blogspot.com; \\ javierruizphd@gmail.com \\ 3. Herbarium, University of Michigan, Ann Arbor, Michigan. USA. \\ * Corresponding author.
}

Received 17-VIII-2009. Corrected 20-III-2010. Accepted 30-IV-2010.

\begin{abstract}
One of the strongest hypothesis about the maintenance of tree species diversity in tropical areas is disturbance. In order to assess this, the effect of intensive natural disturbances on forest growth and mortality in a thinning canopy was studied after the landfall of hurricane Joan in 1988. We evaluated the growth and mortality rates of the 26 most common tree species of that forest in eastern Nicaragua. Permanent plots were established at two study sites within the damaged area. Growth and mortality rates of all individual trees $\geq 3.18 \mathrm{~cm}$ diameter at breast height were assessed annually from 1990 to 2005. During this period the forest underwent two phases: the building phase (marked by increased number of individuals of tree species present after the hurricane) and the canopy thinning phase (marked by increased competition and mortality). Our results from the thinning phase show that tree survival was independent of species identity and was positively related to the increase in growth rates. The analysis of mortality presented here aims to test the null hypothesis that individual trees die independently of their species identity. These findings were influenced by the mortality observed during the late thinning phase (2003-2005) and provide evidence in favor of a non-niche hypothesis at the thinning phase of forest regeneration. Rev. Biol. Trop. 58 (4): 1283-1297. Epub 2010 December 01.
\end{abstract}

Key words: hurricane regenerating forest, relative growth rate, tree mortality, non-niche hypothesis.

A central concern in community ecology is how some communities contain a large number of species while others only a few. A fundamental question derives from the paradox that while some organisms appear to have similar niches, and thus should succumb to the competitive exclusion principle, they seem to coexist over time (Hutchinson 1961). Tree communities in tropical rain forests are examples that contain hundreds of trees species coexisting in a given area, while in temperate rain forests, such an area would contain only 10 to 20 (Stevens 1992). This question has become the focus of much research seeking to detect and understand the mechanisms responsible for such high diversity co-occurrence (Connell 1978, Hubbell \& Foster 1986, Tilman 1994, Hurtt \& Pacala 1995, Hubbell et al. 1999, Gilbert et al. 2001, Chave et al. 2002).

Among the many factors thought to be responsible for the maintenance of tree species diversity is disturbance. The role of periodic disturbances as the force that organizes ecosystems has long been recognized (Connell 1978, Mooney \& Gordon 1983, Pickett \& White 1985). The fundamental idea is known as the intermediate disturbance hypothesis (Connell 1978, Huston 1979). Its rationale is that while species with similar niches may be expected to exclude each other, if some regular disturbance 
event repeatedly resets populations to initial densities, then the competition process will not lead species to competitively exclude one another. Disturbances in tropical rain forests may range from a light-gap resulting from tree falls in a closed canopy (Brokaw 1985), to massive damage by tropical storms (Yih et al. 1991). Because hurricanes, typhoons and cyclones occur with regular frequency in tropical areas, their influence on forest composition and structure can be of particular importance (Lawrence et al. 1991, Vandermeer et al. 2001). Given that the time frame of tropical rain forest tree lifespan is hundreds or thousand of years, even rare hurricanes can be considered as common events from a tree demography standpoint.

This study incorporates the relation between tree species growth and mortality at the thinning canopy of the regenerating forest, thus adding a new research line to our previous work focusing on understanding of forest patterns succession after hurricane Joan in eastern Nicaragua (Vandermeer et al. 1990, Vandermeer et al. 2001, Yih et al. 1991, Boucher et al. 1994). We propose that post-storm forest succession can be thought of as a two-stage process (Granzow et al. 1997) (Fig. 1, 2), involving the direct regeneration from resprouting and seedlings growth into a low stature but very dense canopy, followed by thinning (mortality) of its members through competition (Vandermeer et al. 1990, Vandermeer 1996, Vandermeer et al. 2001). Tree position in the early thinning canopy (Vandermeer et al. 2001) and development of the thinning canopy show that tree mortality is independent of species identity, as analyzed earlier by Zagt \& Werner (1998). As the thinning canopy develops, some individual trees will become dominant due to their high growth rate while others become suppressed due to competition. It is in this thinning canopy where competition will eventually reduce the population to some density approximately equal to the original density (Vandermeer \& Granzow-de-la-Cerda 2004). As thinning progresses, it would also be possible to identify two canopies, one made of individuals that are beginning to dominate the competition process and another made of those being suppressed (Vandermeer \& Granzow-de-la-Cerda 2004). The present study seeks to query the niche (equilibrium) versus non-niche (nonequilibrium) explanation of species diversity in the thinning canopy, following the framework of Zagt \& Werger (1998). Non-niche explanations propose that tree growth and mortality is independent of their species identity (Hubbell \& Foster 1986, Hubbell 2001), thus implying that all tree species in tropical rain forests are in competition to fill-in regeneration places as grow forest and development. Zagt \& Werner also reviewed evidence about tree dispersal

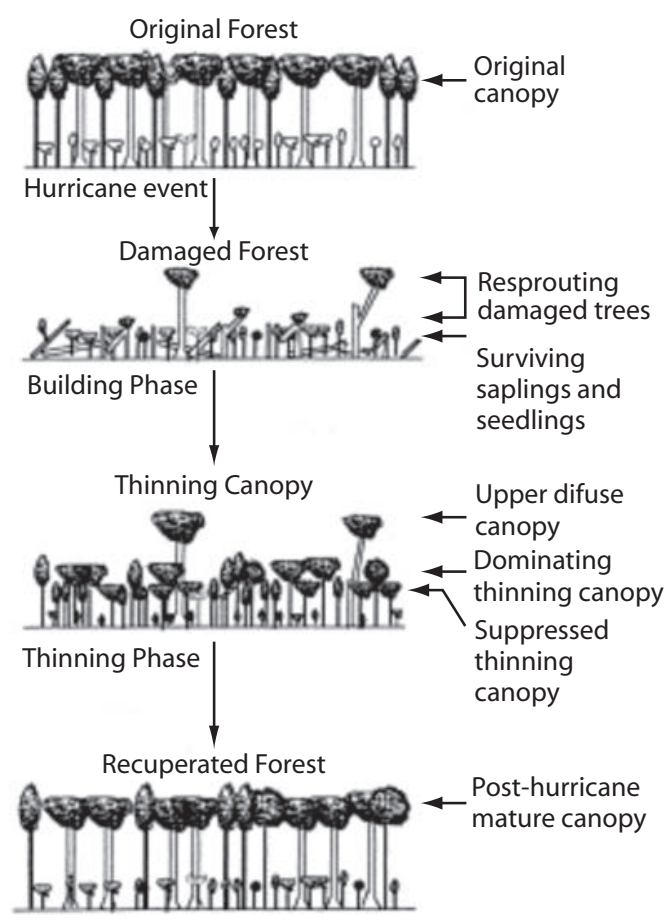

Fig. 1. Representation of growth and mortality at the thinning canopy following forest regeneration after a hurricane. The first cartoon represents the structure of the forest before hurricane, the second after hurricane, the third after late thinning canopy has been 're-built' and the fourth cartoon shows a recuperated forest, with the same physical structure as the original canopy, but with a different set of species and a different distribution of individuals within the species. 
and germination of seedlings, followed by the establishment of advanced regeneration.

In this paper we aim to further our understanding of the effect of intense disturbances on forest regeneration dynamics and tree diversity. Specifically, we ask the following question: Does growth and survival of individual trees depend on the specific identity of the tree during the thinning phase of forest recuperation?

\section{MATERIALS AND METHODS}

Study sites: The study area is located within a $50 \mathrm{~km}^{2}$ swath that was severely damaged by hurricane Joan in 1998 (Fig. 2). This region's climate is characterized by a high rainfall season with a dry period from midJanuary through April. The vegetation is mostly evergreen lowland forest, similar to that which prevails throughout the Caribbean Coast of Mesoamerica. Soil maps and casual observations show its soils to be predominantly Ultisols. Two research sites were chosen within the hurricane disturbed forest area: one, named "Fonseca" 28km north of the trajectory of the hurricane's eye suffered less intense winds; and the other, "Bodega" $14 \mathrm{~km}$ south of the trajectory, thus suffering more intense winds and located near the center of the disturbed area.

Disturbance history: La Bodega was the more damaged site from hurricane Joan. Most tree species regenerated from seedlings or resprouted from snapped off or fallen trunks. At Fonseca site, the forest canopy, although snapped off, resisted the hurricane. Our field observation strongly showed that the most damage sites presented the higher species accumulation curve (Vandermeer et al. 2000). The forest at Fonseca was subsequently damaged by Hurricane Cesar in 1996. Hurricane Cesar was a category two hurricane that snapped off branches of large trees thus forming several light-gaps in one of the transects (Ruiz 1996). Transects at Fonseca site had to be abandoned two years after their destruction by fire following the 1998 ENSO event. The initial damage variability allowed us to evaluate forest regeneration after the massive hurricane Joan, milder hurricane Cesar and the low intensity forest fires associated with the 1998 ENSO event.

Circumference and height measurement: Three $100 \times 10 \mathrm{~m}$ strip plots were established in 1989 and 1990 at each site with two additional 50x30m rectangular plots at Bodega in 2000 and 2001. One of transects at Bodega became repeatedly damaged by brush fires starting in 1994 and thus was eliminated from the analyses. - the total research area is 1.1 ha.

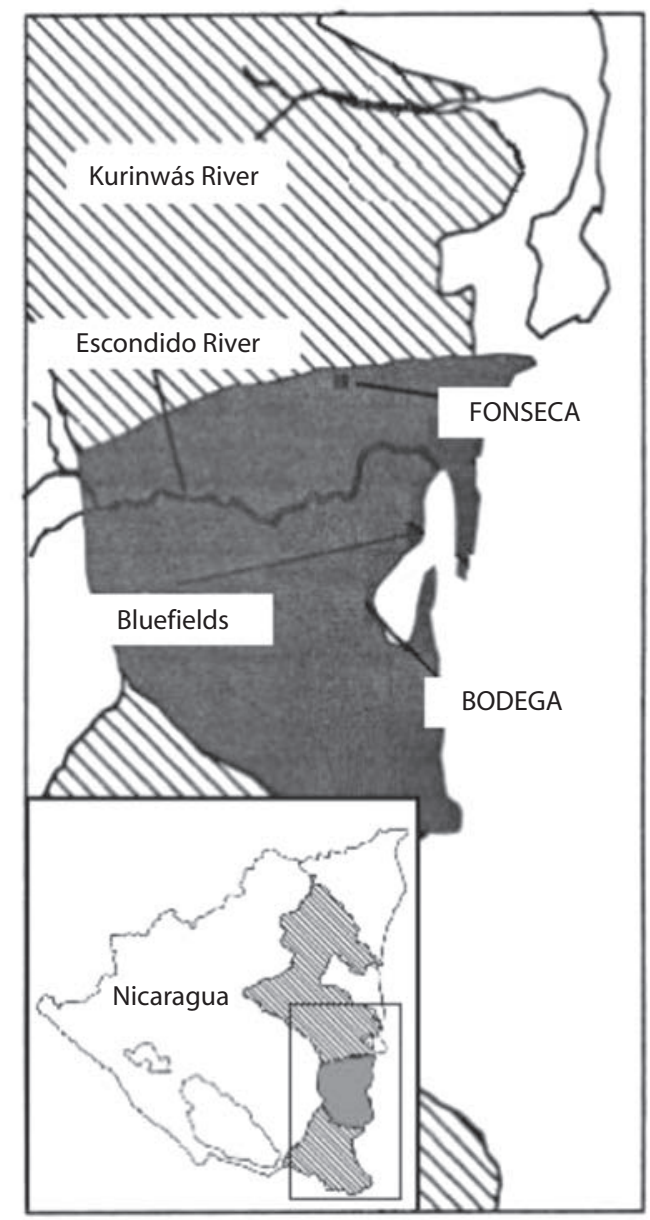

Fig. 2. Study sites. Shaded area: damaged by the hurricane and hatched area: distribution of the tropical rain forest in Nicaragua. 
All trees $\geq 10 \mathrm{~cm}$ in circumference at breast height $(3.18 \mathrm{~cm}$ in diameter) were located and numbered with an aluminum tag affixed with an aluminum nail. All those individuals were measured annually at the same height on the bole.

Only species with more than five individuals $\geq 10 \mathrm{~cm}$ in circumference $(3.18 \mathrm{~cm}$ dbh) were included in the study. Trees were identified in the field and vouchers deposited at the National Herbarium of Nicaragua (HNMN) and the University of Michigan Herbarium (MICH). Earlier vouchers were deposited at Instituto Nacional de la Biodiversidad (INBIO) in Santo Domingo, Costa Rica.

Relative growth rates: Yearly growth in circumference was measured as the change in circumference; where relative growth rate (RGR) is calculate by the formula:

$$
R G R=\ln (X(t+1))-\ln (X(t))
$$

where $\ln (X(t))$ is the natural logarithm of the circumference at breast height at time $t$ and $\ln (X(t+1))$ at time $t+1$. RGR represents the rate at which the circumference is growing or diminishing.

Because growth rates depend on the size of the individual during forest regeneration phases, we corrected the relative growth rate estimate for size. Weighted RGR* was categorized into five size classes; 10-24, 25-40, $41-60,61-120$ and over $120 \mathrm{~cm}$. Weighted relative growth rate is calculated as follow:

$$
R G R^{*}=\frac{n_{1}\left[\ln \left(X_{I}(t+1)\right)-\ln (X(t))\right]+\ldots+n_{5}\left[\ln \left(X_{5}\left(t_{4}+1\right)\right)-\ln \left(X\left(t_{4}\right)\right)\right]}{N}
$$

where $n_{1}$ and $n_{5}$ is the number of trees in the first and fifth size stage. $\mathrm{N}$ is the total sample size. $\ln \left(X_{l}(t)\right)$ is the natural logarithm of the circumference at breast height for the first stage at time $t$ and $\ln \left(X_{I}(t+1)\right)$ at time $t+1$, respectively. In general, smaller trees experience faster growth rates early in the building phase, but during the canopy thinning phase all individual tree have lower growth rates because they have either reached their maximum size or are experiencing intense competition.

Tree mortality patterns in the thinning canopy: Individuals were classified as dead when the crown lacked green leaves and the stem was dry. Individuals regarded as dead for the first time were not excluded until their status as dead was confirmed in the following 1-2 years, as some reverted to living status the following year. For individuals not found, their aluminum tag was searched for on the ground. Not until this was found lying or attached to a fallen stem, was a missing tree reported as dead.
All trees that died each year between 1990 and 2000 at Fonseca and between 1990 and 2005 at Bodega were recorded. Overall probability of mortality was calculated as the total mortality count (all mortality records of all species per period) divided by the total number of individuals of all species per year. The probability of mortality for each species was calculated as follows: the total mortality multiplied by the number of dead individuals per species. Thus the result is the expected number of individuals that died per species. For species where estimated mortalities were less than five death counts, the estimation of the number of dead trees were lumped until at least five deaths were counted. We used a $\chi^{2}$-test with a Bates correction in order to test whether there were statistical significant differences between the observed and the expected tree mortality. Degrees of freedom were reduced by one because the mortality rate was estimated from the data (Sokal \& Rohlf 1981). 
Tree growth and fate in the thinning canopy: RGRs were compared between individual trees that survived versus individuals that died during a given period $(t, t+1)$. We used tree condition (alive or death) as the independent variable and tree growth was used as the dependent variable in each site. RGRs between dead and live individuals were analyzed with a $t$ test for independent samples in order to verify the null hypothesis that surviving trees have on average faster RGR than dead ones in the previous year.

\section{RESULTS}

Circumferences and height distributions in two regenerating forests: The platykurtic circumference distribution of Figure $3 \mathrm{a}$, is skewed toward smaller individuals because of their greater abundance in the regenerating hurricane forest. Patterns in circumference are consistent between both sites, but some particularities exist. In 1996, circumference distributions were centered at around $20 \mathrm{~cm}$ at Fonseca, mainly because much of the regeneration is from seedlings and re-sprouts from fallen trunks into the forest canopy (Fig. 3a). In figure 4 , the skewedness coefficient with respect to the mean circumference distribution is very low from 1990 to 1997. For example, the circumference distribution is more homogeneous during the first years at Fonseca than at Bodega (Fig. 4), which is perhaps due to the fact that La Bodega site was more heavily damaged by hurricane Joan (Vandermeer \& Granzow-de la Cerda 2004). However, due to the light-gaps formation by hurricane Cesar at Fonseca site, the skewedness index increased following the transition from smaller to larger circumference sizes after this hurricane at Fonseca.

At Bodega site circumference distributions were biased toward smaller-size classes since the beginning of the study. Later, during the thinning phase, circumference distributions were centered on $30 \mathrm{~cm}$ (Fig. 3b). This pattern is due, to a large extent, to the fast growing species, Vochysia ferruginea, a species that has become the most dominant, since the earliest post-hurricane regeneration stages at Bodega site (Boucher et al. 1994). The right-hand tail of the circumference distributions is due to the presence of emergent trees that are forming a diffuse upper canopy $(\sim 30 \mathrm{~m})$. In this diffuse canopy Dipteryx oleifera and Hieronyma alchorneoides are the most common species. The skewedness coefficient of circumferences decreases in part due to the growth of small trees, thus leading to a circumference distribution centered on individuals present at the thinning canopy in recent years (Fig. 4).

The analysis of the circumferences during the thinning phase shows the unsurprising fact that larger trees grew more than smaller ones. In Figure 5 we present the growth pattern of tree circumference at the early thinning canopy for Fonseca site (Fig. 5a) and the growth pattern of tree circumference during the thinning canopy for Bodega (Fig. 5b). The points near the origin correspond to small trees that were present in the lower canopy stories. In general, small trees were suppressed due to low light conditions created by the compact thinning canopy above and the low number of light gaps subsequent to the 'building phase' (Vandermeer et al. 2001). There is a tendency to continue growing once a tree reaches the early thinning canopy, those trees are approximately $>20 \mathrm{cms}$ in circumference. Points below the 45 degrees line represent trees that diminished in circumference due to competition. This could reflect a thinning process, as the death rate was concentrated among these small sized individual trees.

Mortality patterns in the thinning canopy: The results show that there were species with mortality consistent with the mortality expectation and others that were above or below the expected mortality (Table 1). The direction of the bias of the observed mortality with respect to the expected mortality in each species is very similar in both sites - that is, there was only one species with a minimal reverse bias under the expectation of neutral mortality in one site with respect to the other site. This exception being $V$. ferruginea, with 


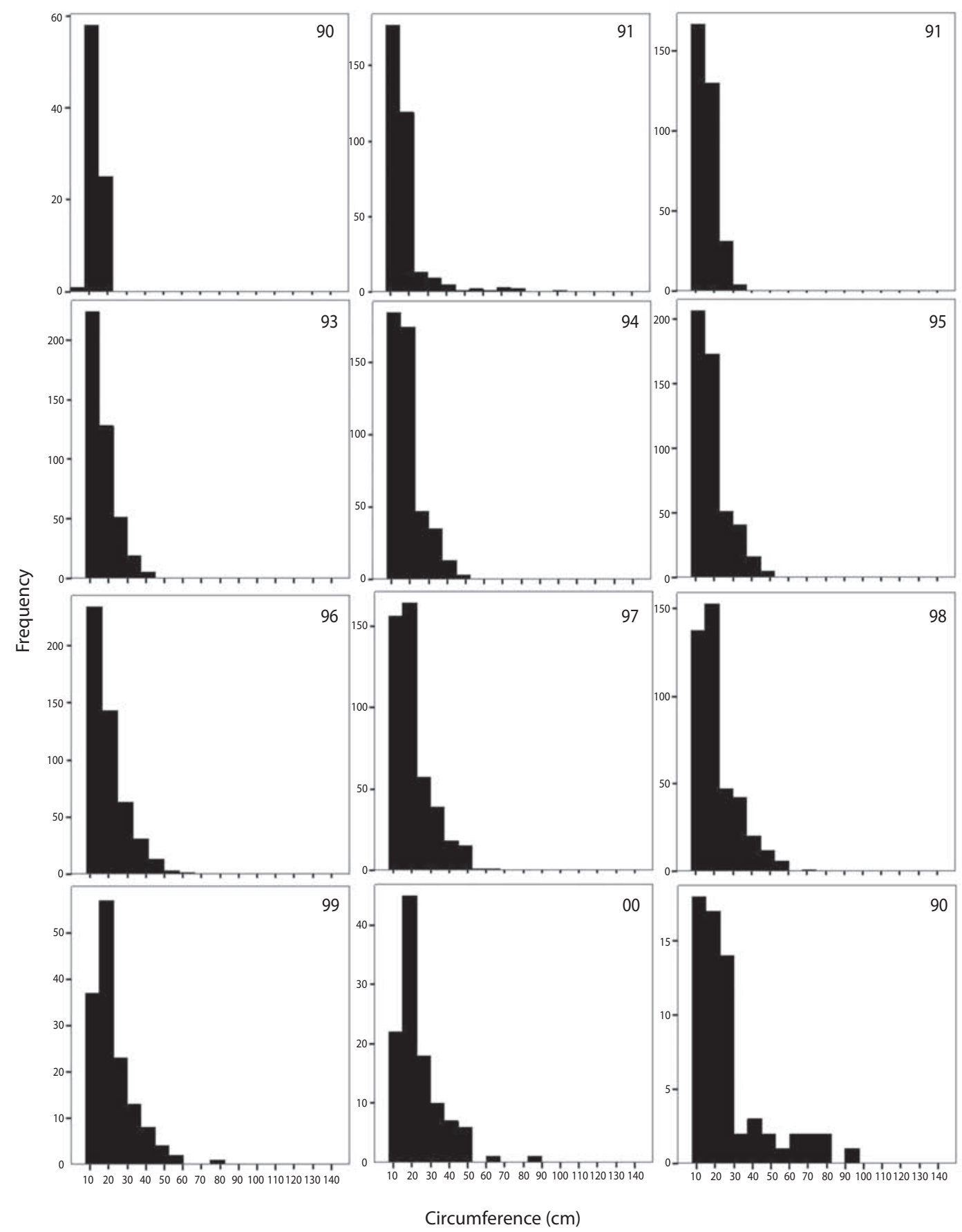

Fig. 3. a) Histogram for yearly circumference distributions at Fonseca (for each year between 1990 and 2000. Sub-chart in the lower right hand size corresponds to Bodega 1990. 


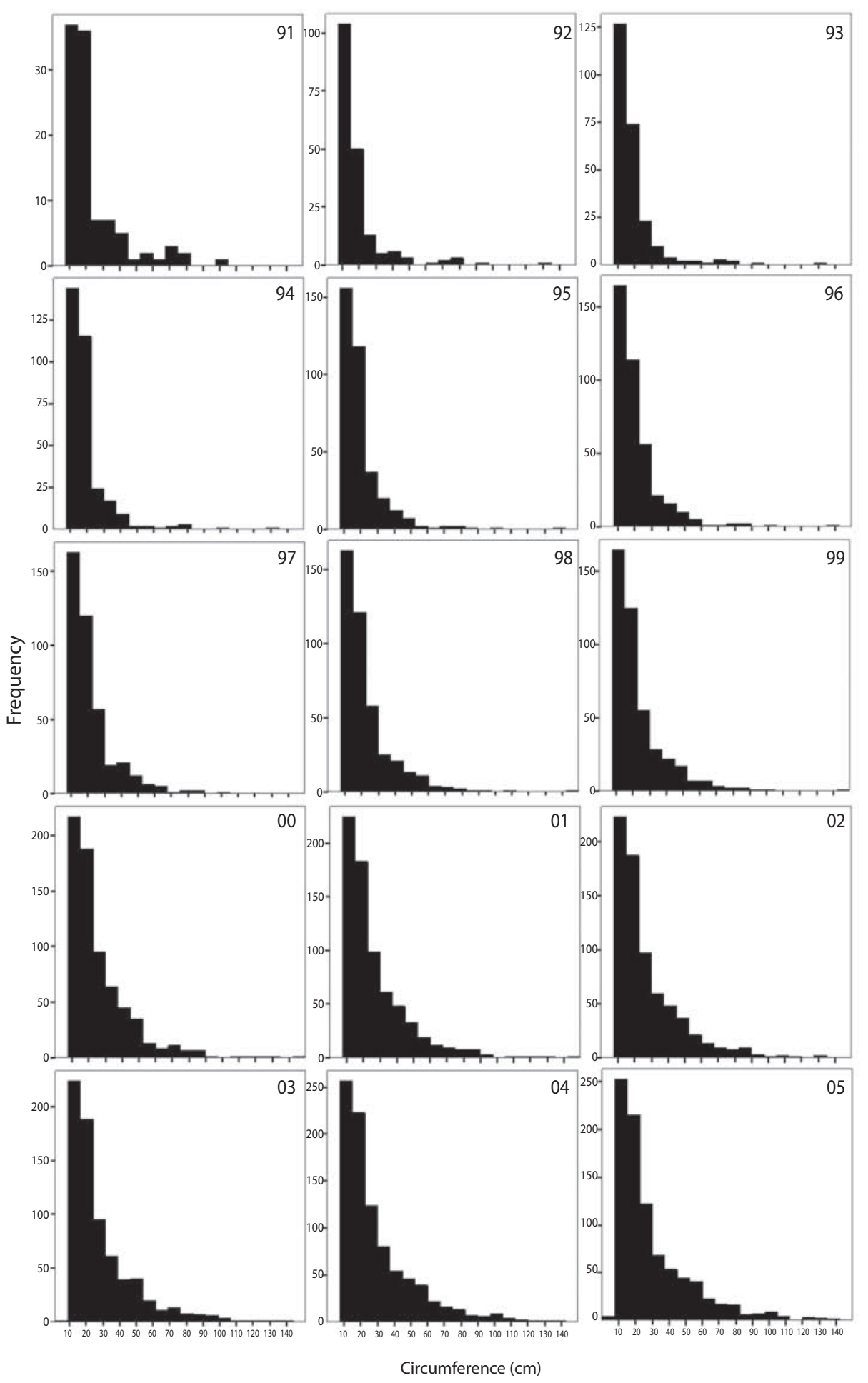

Fig. 3. b) Circumference distributions at Bodega for each year between 1991 and 2005. 


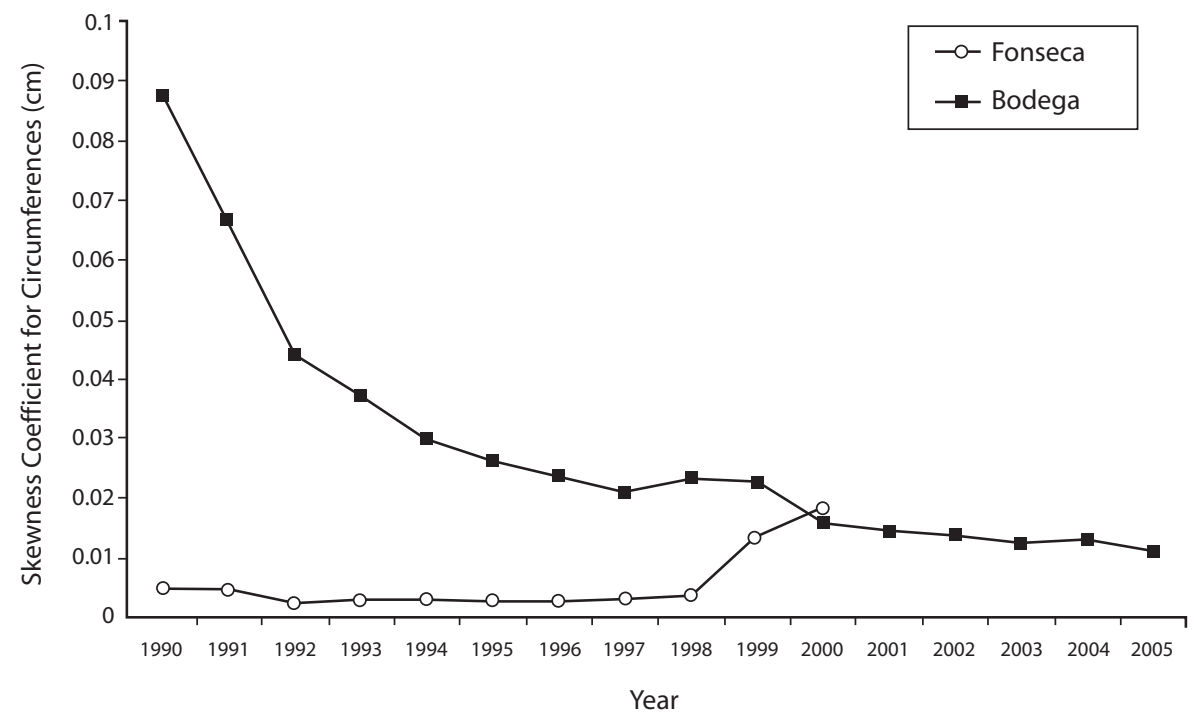

Fig. 4. Skewedness coefficient for circumference at Fonseca site and Bodega site.

TABLE 1

Actual number of individuals in 2000 (F=Fonseca) and 2005 (B=Bodega) and number of observed mortality events in two sites of a hurricane forest in eastern Nicaragua

\begin{tabular}{rlccc} 
Site & \multicolumn{1}{c}{ Taxon } & $\begin{array}{c}\text { Density in } 2000(\mathrm{~F}) \\
\text { and } 2005(\mathrm{~B})\end{array}$ & $\begin{array}{c}\text { Observed Mortality } \\
\text { (whole period) }\end{array}$ & $\begin{array}{c}\text { Expected Mortality } \\
\text { (whole period) }\end{array}$ \\
Fonseca & Amaioua corymbosa & 5 & 8 & 10 \\
Fonseca & Byrsonima crassifolia & 10 & 19 & 19 \\
Fonseca & Galipea granulosa & 11 & 35 & 37 \\
Fonseca & Guatteria recurvisepala & 12 & 35 & 36 \\
Fonseca & Guettarda combsii & 7 & 18 & 18 \\
Fonseca & Hirtella guatemalensis & 3 & 11 & 11 \\
Fonseca & Isertia haenkeana & 4 & 42 & 42 \\
Fonseca & Manilkara zapota & 5 & 16 & 16 \\
Fonseca & Miconia prasina & 23 & 75 & 74 \\
Fonseca & Pseudolmedia spuria & 3 & 16 & 16 \\
Fonseca & Rinorea squamata & 8 & 41 & 40 \\
Fonseca & Vochysia ferruginea & 13 & 66 & 65 \\
& Total & 104 & 382 & 384 \\
Bodega & Byrsonima crassifolia & 29 & 5 & 5 \\
Bodega & Cupania glabra & 71 & 5 & 8 \\
Bodega & Dendropanax arboreus & 25 & 67 & 13 \\
Bodega & Inga cocleensis & 51 & 7 & 4 \\
Bodega & Lacistema aggregatum & 24 & 5 & 6 \\
Bodega & Miconia prasina & 67 & 10 & 6
\end{tabular}



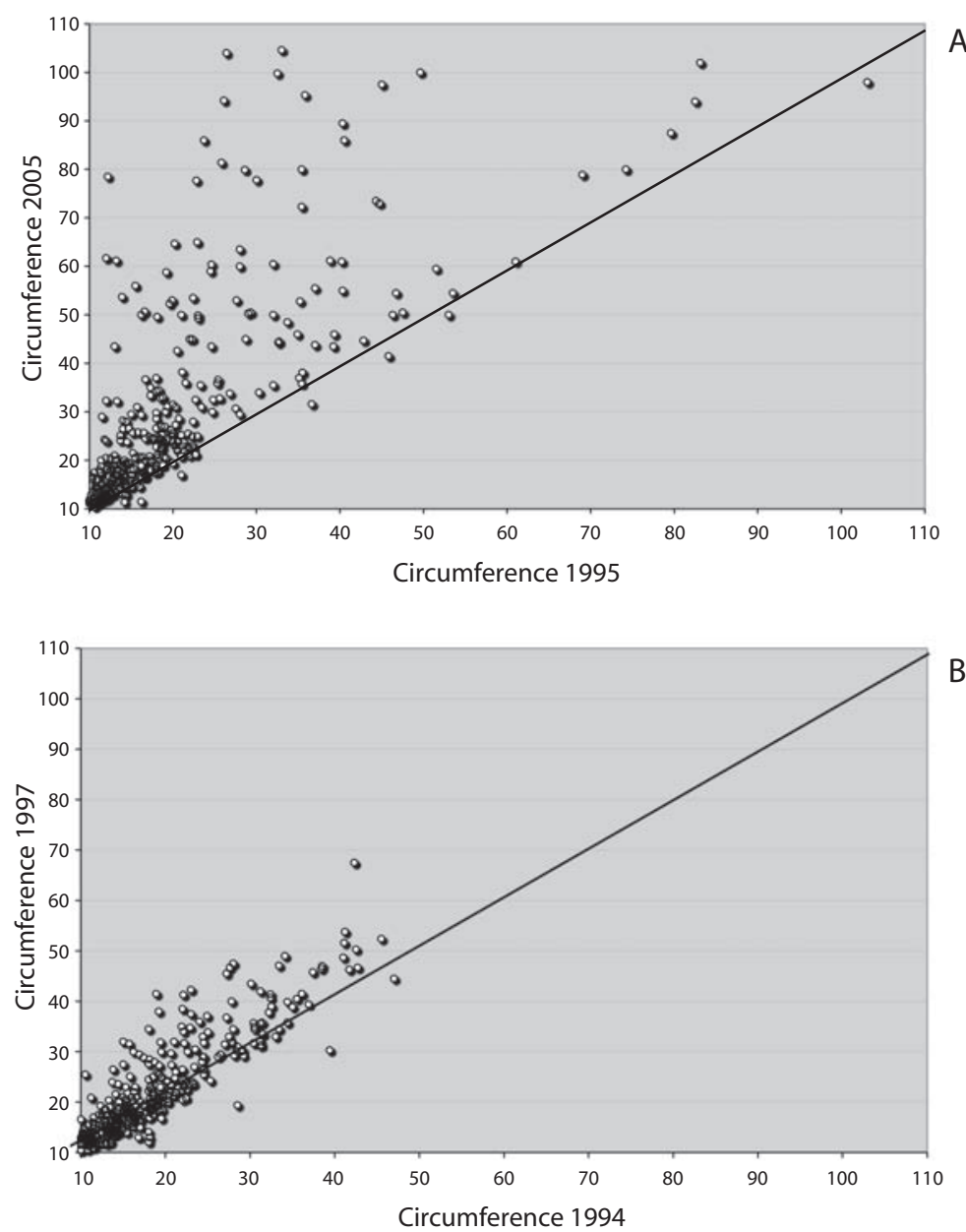

Fig. 5. Growth patterns in circumference for tree species in the hurricane forest of eastern Nicaragua between 1994 and 2005. Solid line represents a $45^{\circ}$ line with respect to the origin. Open circles represent trees at the building canopy at Fonseca site (a) and thinning canopy at Bodega site (b). Circles close to the origin represent trees that in general are diminishing; tree mortality is concentrated in these size categories.

a mortality expectation slightly larger than the neutral mortality expectation at Bodega site, where it is the most abundant tree (Boucher \& Granzow de la Cerda 2008). Survival of $V$. ferruginea was higher than for most tree species in the thinning canopy. At Fonseca site the observed mortality for this species is slightly lower than the neutral mortality expectation (Table 1). Before hurricane Cesar, V. ferruginea was the second most abundant species, and subsequently to hurricane Cesar increased in abundance.
Observed mortalities and expected neutral mortalities are remarkably similar at Fonseca $\left(\chi^{2}=0.3135, \mathrm{df}=12, \mathrm{p}=0.9999\right.$, Table 1$)$. Because, tree demography data were binned across time for each site, the results show that the occurrence of low intensity forest fires at Fonseca affected trees independent of their species identity and demography. We think that tree mortality at Fonseca is mainly due to the kind of forest fire damage to the forest understory, not due to the process of thinning since the thinning canopy was not constructed 
until later. Forest fires burned small trees, while larger trees were damaged at their base but sufficiently so to lead to high mortality during the following year (Ruiz et al. 2001). Consequently, the site was abandoned after the yearly census in 2000.

Observed tree species mortalities do not differ from a neutral expectation at Bodega site from 1990 to 2005. An apparent, but not statistically significant, exception is Dendropanax arboreus, with an expected morality of 13 individuals and only 6 individuals actually dying $\left(\chi^{2}=3.053, \mathrm{df}=6, \mathrm{p}=0.8022\right.$, Table 1$)$. The species is a fast growing canopy tree species and produces a large number of seedlings each year at Bodega (personal observation). Its abundance appears to be the result of the success of its advanced regeneration in reaching the thinning canopy. In recent years the species seems to be among those filling small light-gaps. When the species is removed form the analysis the observations still do not differ from a neutral mortality expectation $\left(\chi^{2}=1.312\right.$, $\mathrm{df}=5, \mathrm{p}=0.9336$ ). From 2000 to 2005 (the thinning phase), the results also support the idea that tree mortality is a random process with respect to species identity at Bodega site $\left(X^{2}=5.001, \mathrm{df}=6, \mathrm{p}=0.5436\right)$.

Tree growth and survival in the thinning canopy: The trend of species relative growth rates decreases as forest recovery proceeds. Initially, trees grew very fast, taking advantage of the post-hurricane light conditions, followed by a reduction in growth rates as the thinning phase of forest regeneration progresses $\left(\mathrm{r}^{2}=0.1940 \pm \mathrm{SE}=0.051\right.$, slope $=-0.44, \mathrm{p}=0.000$; Fig. 6). The variation in RGRs with respect to the linear regression is due to several exceptions to the general pattern (Fig. 7). For example, $V$. ferruginea, which had higher growth rates than all other species. However, the growth pattern of $V$. ferruginea is consistent with the overall growth dynamics in the post-hurricane forest. The canopy emergent trees that resisted the hurricane had growth rates very close to zero (i.e.

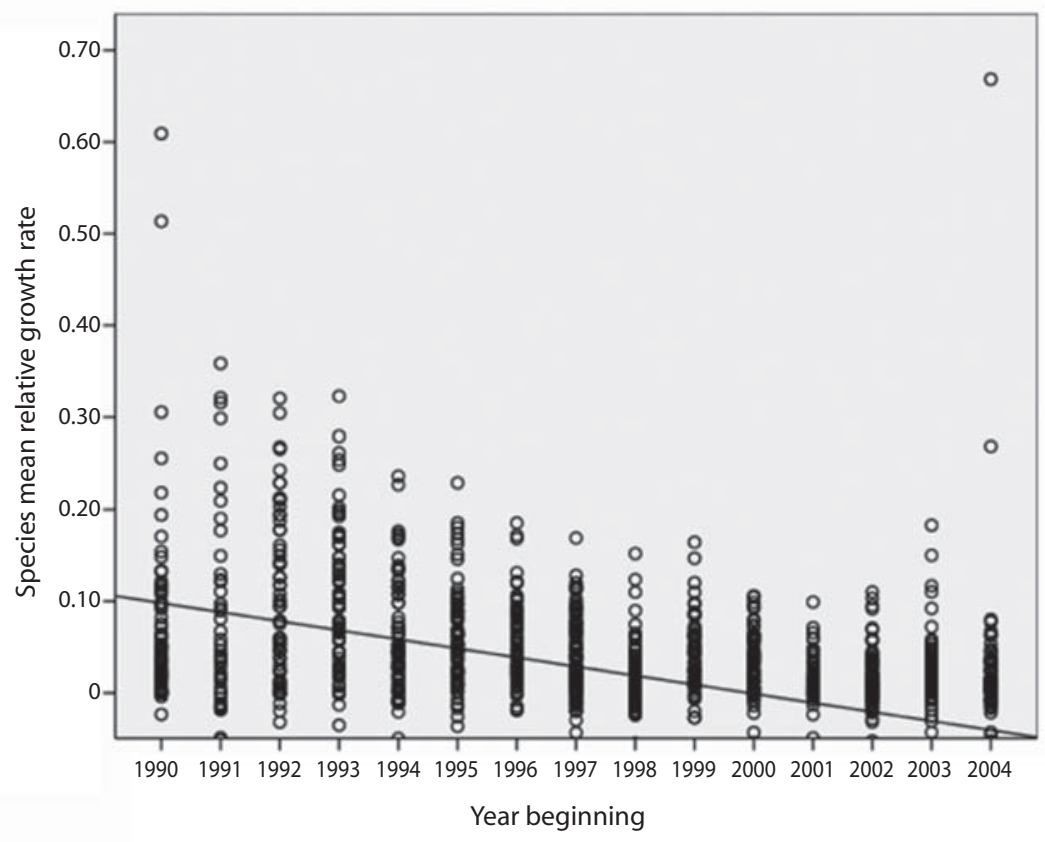

Fig. 6. Weighted mean relative growth rates for Fonseca and Bodega site combined (open circles). Solid line represents a linear regression fit. 


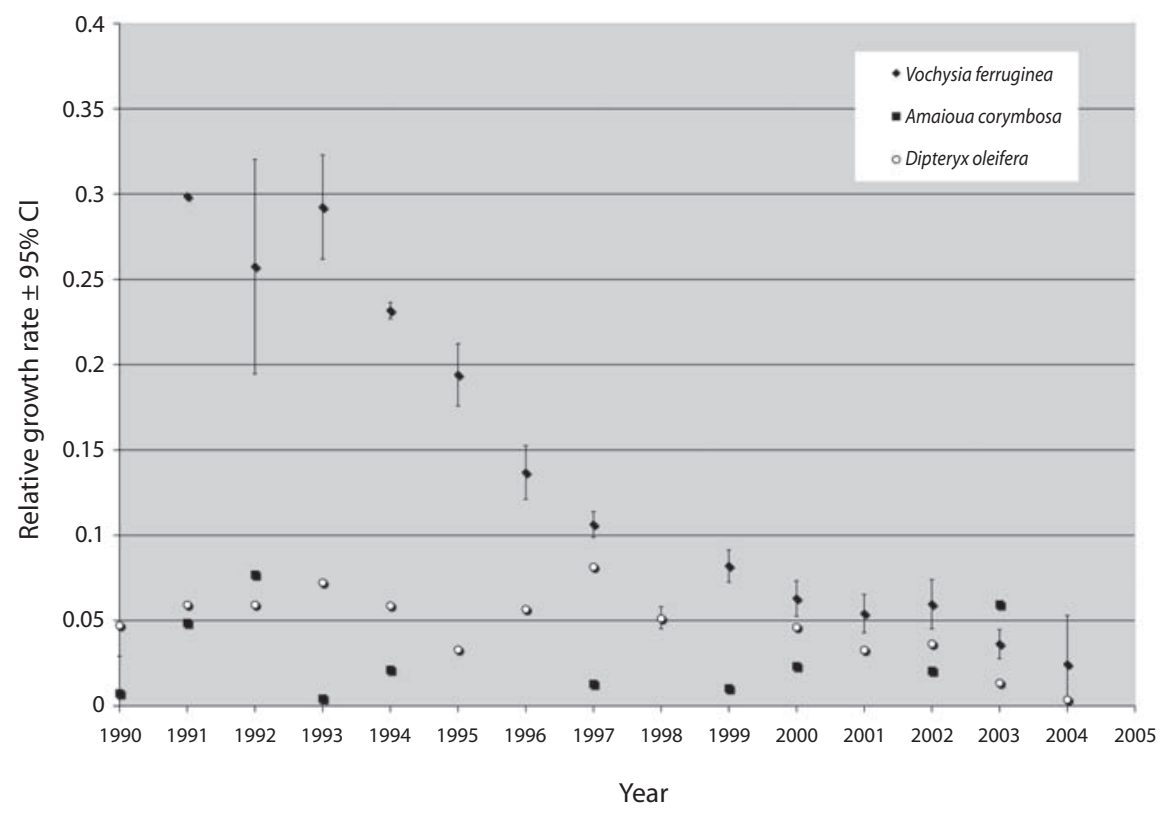

Fig. 7. Weighted mean relative growth rates for V.ferruginea, A. corymbosa and D. oleifera at Fonseca and Bodega site.

Dipteryx oleifera, Hieronyma alchorneoides), because they were at or near their maximum sizes. Others, like Amaioua corimbosa, also had growth rates very close to zero throughout the research period, because understory species reached maximum size during the building phase of the recovering phase, first five years after hurricane Joan.

The examination of relative growth rates between survivor and dead trees showed the unsurprising fact that tree survival is positively related to fast growth rates in both research sites. In Table 2, tree mortality is significantly and positively related to slower RGR in the thinning canopy. In sum, these findings support the fundamental proposition of a random mortality with respect to species identity at the thinning canopy, where survival is positively related to faster growth rates.

\section{DISCUSSION}

The present study seeks to query the niche (equilibrium) versus non-niche (non- equilibrium) explanation of tree species diversity, following the framework of Zagt \& Werger (1998). To do so, we have divided the postdisturbance forest succession process into two main phases, the building phase and the thinning phase. Zagt \& Werger (1998), reviewed evidence about these two phases, effectively recognizing a wider range of phenomena in their analysis. Their analysis begins before the occurrence of the disturbance, with seed dispersal and germination of seedlings, followed by the establishment of the advanced regeneration or, what would be equivalent in our case, the seedlings and sapling recruitment dynamics before and after the hurricane Joan. Our work here begins at a later point in the process of forest recovery, evaluating the pattern of tree recruitment, growth and mortality in the thinning canopy. We use Figure 8 to summarize what we think to be the overall pattern, from the seedling arrival at a point in forest floor to the recruitment of an adult tree at that point in the forest canopy, in the same context that was analyzed earlier by Vandermeer et al. (2001). 
TABLE 2

Results for independent samples of t tests in two sites of a hurricane forests in eastern Nicaragua. Numbers in bold indicate statistically significant results

$\begin{array}{rcccccccc}\text { Site } & \text { Period } & \mathrm{t} & \mathrm{df} & \mathrm{p} & \mathrm{S} \text { ite } & \mathrm{t} & \mathrm{df} & \mathrm{p} \\ \text { Bodega } & 1990-1991 & -0.8852 & 18 & 0.3877 & \text { Fonseca } & 0.0088 & 17 & 0.9931 \\ \text { Bodega } & 1991-1992 & 0.3830 & 28 & 0.7046 & \text { Fonseca } & -0.2634 & 25 & 0.7944 \\ \text { Bodega } & 1992-1993 & 0.4226 & 32 & 0.6754 & \text { Fonseca } & -0.1124 & 26 & 0.9114 \\ \text { Bodega } & 1993-1994 & 0.3961 & 33 & 0.6946 & \text { Fonseca } & -1.0329 & 26 & 0.3112 \\ \text { Bodega } & 1994-1995 & 1.0912 & 34 & 0.2829 & \text { Fonseca } & -0.1776 & 26 & 0.8604 \\ \text { Bodega } & 1995-1996 & -0.1135 & 37 & 0.9103 & \text { Fonseca } & -0.4172 & 26 & 0.6799 \\ \text { Bodega } & 1996-1997 & 0.8115 & 37 & 0.4223 & \text { Fonseca } & 0.4443 & 26 & 0.6605 \\ \text { Bodega } & 1997-1998 & 0.4770 & 37 & 0.6362 & \text { Fonseca } & -0.9017 & 26 & 0.3755 \\ \text { Bodega } & 1998-1999 & 2.0645 & 37 & \mathbf{0 . 0 4 6 0} & \text { Fonseca } & -1.2809 & 22 & 0.2136 \\ \text { Bodega } & 1999-2000 & 0.4434 & 37 & 0.6601 & & & & \\ \text { Bodega } & 2000-2001 & 0.0627 & 38 & 0.9503 & & & & \\ \text { Bodega } & 2001-2002 & -1.7613 & 39 & \mathbf{0 . 0 8 6 0} & & & & \\ \text { Bodega } & 2002-2003 & -0.6730 & 39 & 0.5049 & & & & \\ \text { Bodega } & 2003-2004 & -1.6894 & 38 & \mathbf{0 . 0 9 9 3} & & & & \end{array}$

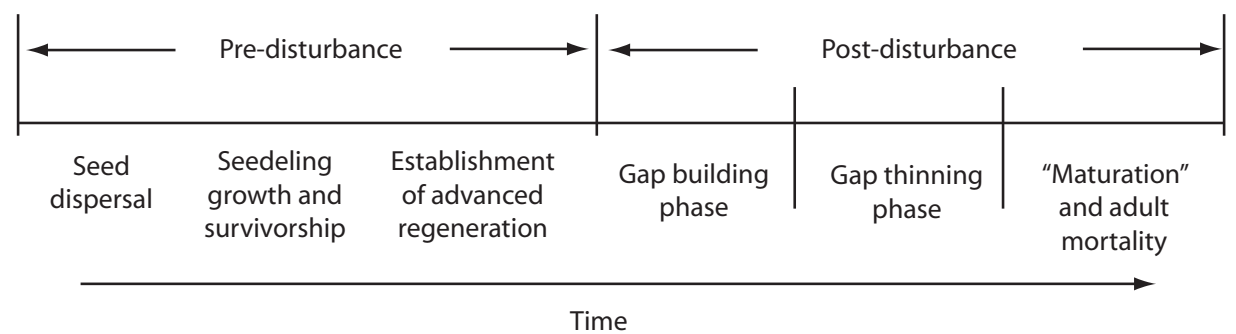

Fig. 8. General pattern of forest succession after the effect of disturbance.

In their communication Zagt \& Werger (1998) emphasized both ends of this spectrum, suggesting that seedlings might exhibit different community assemblage properties from adults. As suggested by Zagt \& Werger (1998), most studies emphasize either the early phases of the overall process (the left hand side of Fig. 8) or the late phases (right hand side of Fig. 8).

Our work focuses on the late thinning stage of forest regeneration dynamics following disturbance by Hurricane Joan of 1988. Earlier fieldwork focused on recruitment into the building canopy and the early thinning canopy, strongly supporting the non-niche framework for the building phase of post disturbance succession (Vandermeer et al. 1996). Similar to the findings of a field study at Barro Colorado Island in Panama by Hubbell (1999) and Hubbell et al. (1999), which found evidence in favor of a non-niche model in terms of mortality of adult trees in the mature phase of forest succession (Wills et al. 1997). Here we analyze the late thinning process - 'gap thinning phase' the right hand side of the graphic in Figure 8 and find evidence for a non-niche interpretation during late thinning phase. The results reported 
herein are in contrast to the general niche interpretation presented earlier (Vandermeer et al. 2001). This early work was acknowledged as preliminary and was accomplished before the number of mortality events was sufficiently large. The results reported here contradict those early findings. In addition, here we evaluate the growth versus survival tradeoff during the process of forest regeneration. The results strongly support a non-niche interpretation based on tree species growth performance into the late phase of the thinning canopy.

In summary, we present evidence in favor of the growing literature that rejects a strict niche interpretation of tropical rain forest organization (Clark \& Clark 1985, Alvarez-Buylla \& Martinez-Ramos 1991, 1992, Clark \& Clark 1992, Hubbell 1999, Hubbell et al. 1999, Ruiz et al. 2009). Although, data clearly show that tree species are randomly experiencing mortality during the thinning phase of forest regeneration, this observation is not a consequence of Swain \& Whittmore's (1988) provisional rough-cut of the pioneer versus primary forest dynamic, since pioneers have been excluded from the mortality analysis because the marked dichotomy in growth and survival rates between pioneer tree species and other tree species (Vandermeer et al. 2001). Rather, as suggested by Alvarez-Buylla \& Martínez-Ramos (1991) and by Hubbell (1995), these two categories may represent extremes on a continuиm of tree life histories. Our data support the idea that there are no species-specific niches during either the building phase or the thinning phase of forest regeneration. This result corroborates the prediction about a random pattern of tree mortality in the thinning canopy (Vandermeer \& Granzow-de-la-Cerda 2004). The results here, in combination with the results obtained by Vandermeer et al. (2001), strongly support the ideas of Zagt \& Werger (1998), that a nonniche (non-equilibrium) interpretation applies to the building and thinning phase, yet leaves open the possibility that a niche (equilibrium) based assembly might ultimately take please during the mature forest stage - the core of future field research.

\section{ACKNOWLEDGMENTS}

This work was supported by the National Science Foundation grants (BSR-8917688, DEB 9524061, and DEB 0235761) to John Vandermeer. We wish to thank to the members of Proyecto Biodiversidad de las Universidades de las Regiones Autónomas de la Costa Caribeña Nicaragüense (URACCAN), Centro de Investigación y Documentación de la Costa Atlántica (CIDCA) and Bluefields Indian and Caribbean University (BICU) for logistic support and collaboration in many ways.

\section{RESUMEN}

Estudiamos el efecto de los fenómenos naturales sobre la dinámica de bosques húmedos tropicales del este de Nicaragua después del paso del huracán Juana en 1988. Evaluamos las tasas de crecimiento y mortalidad de las 26 especies más comunes en ese bosque posterior al huracán. El estudio se llevó a cabo en dos localidades del área afectada por el huracán. Establecimos parcelas permanentes en dos sitios afectados por el huracán, en las cuales medimos variables demográficas poblacionales a todos los individuos con un diámetro a la altura del pecho $\geq 3.18 \mathrm{~cm}$. El estudio se realizó durante dos fases, la fase de construcción de dosel (caracterizada por el aumento en el número de individuos de las especies que resistieron el huracán) y la fase de raleo del dosel (caracterizado por el aumento de la competencia y mortalidad). El análisis de la mortalidad en la etapa de raleo del dosel trata de probar la hipótesis que la mortalidad de los árboles no esta ligada a la identidad de especies de árboles y que la sobrevivencia se encuentra directamente relacionada con el crecimiento de los árboles. Asimismo, estos resultados confirman la hipótesis de independencia con respecto a posibles nichos ecológicos.

Palabras clave: regeneración de bosques por huracanes, tasa de crecimiento relativo, mortalidad, hipótesis de independencia de nichos.

\section{REFERENCES}

Alvarez-Buylla, E.R. \& M. Martinez-Ramos. 1991. Seed and forest dynamics: a theoretical framework and an example from the neotropics. Am. Nat. 142: $137-$ 154.

Alvarez-Buylla, E.R. \& M. Martinez-Ramos. 1992. Demography and allometry of Cecropia obtusifolia, a neotropical pioneer tree - evaluation of the climax- 
pioneer paradigm for tropical rain forests. J. Ecol. 80: 275-290.

Boucher, H.D. \& I. Granzow de la Cerda. 2008. Recuperación del dosel del bosque huracanado de La Bodega, río Kukra, R.A.A.S., a los dieciséis años de huracán Juana. Wani 52: 17-21.

Boucher, H.D., J. Vandermeer, M.A. Mallona, N. Zamora \& I. Perfecto. 1994. Resistence and resilience in a directly regenerating rain forest. Nicaraguan trees of the Vochysiaceae after hurricane Joan. J. Forest Ecol. 68: $127-136$.

Brokaw, N.V.L. 1985. Gap-Phase Regeneration in a Tropical Forest. Ecology 66: 682-687.

Chave, J., H.C. Muller-Landau \& S.A. Levin. 2002. Comparing classical community models: theoretical consequences for patterns of diversity. Am. Nat. 159: $1-23$.

Clark, D.A. \& D.B. Clark. 1992. Life history diversity of canopy and emergent trees in a neotropical rain forest. Ecol. Monogr. 62: 315-344.

Clark, D.B. \& D.A. Clark. 1985. Seedling dynamics of a tropical tree: impacts of herbivory and meristem damage. Ecology 66: 1884-1892.

Connell, J.H. 1978. Diversity in tropical rain forest and coral reefs. Science 199: 1302-1310.

Gilbert, G.S., K.E. Harms, D.N. Hamill \& S.P. Hubbell. 2001. Effects of seedling size, El Niño drought, seedling density, and distance to nearest conspecific adult on 6-year survival of Ocotea whitei seedlings in Panamá. Oecologia 127: 509-516.

Granzow-de-la-Cerda, I., N. Zamora, J.H. Vandermeer \& D.H. Boucher. 1997. Biodiversidad de especies arbóreas en el bosque tropical húmedo del Caribe Nicaragüense siete años después del huracán Juana. Rev. Biol. Trop. 45: 1409-1419.

Hubbell, S.P. 1995. Towards a theory of biodiversity and biogeography on continuous landscapes, p. 171-199. In G.R. Carmichael, G.E. Folk \& J.L. Schnoor (eds.). Preparing for Global Change: A Midwestern Perspective. Academic, Amsterdam, Netherlands.

Hubbell, S.P. 1999. Tropical tree richness and resourcebased niches. Science 285: 1459a.

Hubbell, S.P. \& R.B. Foster. 1986. Biology, chance and history and the structure of tropical forest tree communities, p. 314-329. In J. Diamond \& T.J. Case (eds.). Community Ecology. Harper \& Row, New York, USA.
Hubbell, S.P., R.B. Foster, S.T. O’Brien, K.E. Harms, R. Condit, B. Wachsler, S.J. Wright \& S. Loo de Lao. 1999. Light-gap disturbances, recruitment limitation, and tree diversity in a neotropical forest. Science 283: 554-557.

Hubbell, S.P. 2001. The Unified Neutral Theory of Biodiversity and Biogeography. Princeton University, Princeton, USA.

Hurtt, G.C. \& S.W. Pacala. 1995. The consequences of recruitment limitation: reconciling chance, history and competitive differences between plants. J. Theor. Biol. 176: 1-12.

Huston, M. 1979. A general hypothesis of species diversity. Am. Nat. 113: 137-145.

Hutchinson, G.E. 1961. The paradox of the plankton. Am. Nat. 95: 137-145.

Lawrence, R.W., D.J. Lodge \& R.B. Waide. 1991. An introduction to hurricanes in the Caribbean. Biotropica 23: 313-316.

Mooney, H.A. \& M. Gordon. 1983. Disturbance and ecosystem. Springer, Berlin, Germany.

Pickett, S.T.A. \& P.S. White. 1985. Natural disturbance and patchy dynamics. Academic, New York, USA.

Ruiz, J., D.H. Boucher, D. Ruiz-Moreno \& C. IngramFlores. 2009. Recruitment Dynamics of the Tropical Rainforest tree Dipteryx oleifera (Fabaceae) in eastern Nicaragua. Rev. Biol. Trop. 51: 321-338.

Ruiz, J., D.H. Boucher, J.H. Vandermeer, I. Granzow de la Cerda, I. Perfecto \& V. Martínez. 2001. Recuperación Inicial de un Bosque Incendiado y Previamente Afectado por el Huracán Juana en Nicaragua. Revista Encuentro 58: 66-75.

Ruiz, J. 1996. ... En la costa, Un huracán cada siglo? Guía Ambientalista (Managua, Nicaragua), Octubre 1996.

Sokal, R.R. \& F.J. Rohlf. 1981. Biometry. Freeman, New York, USA.

Stevens, G.C. 1992. The elevation gradient in altitudinal range: an extention of rapoport's latitudinal rule to altitude. Am. Nat. 140: 893-911.

Swain, M.D. \& T.C. Whitmore. 1988. On the definition of ecological species groups in tropical rain forests. Vegetatio 75: 81-86.

Tilman, D. 1994. Competition and biodiversity in spatially structured habitats. Ecology 75: 2-16. 
Vandermeer, J. 1996. Disturbance and neutral competition theory in rain forest dynamics. Ecol. Model. 85: 99-111.

Vandermeer, J., H.D. Boucher, I. Perfecto \& I. Granzowde-la-Cerda. 1996. A theory of disturbance and species diversity: Evidence from Nicaragua after Hurricane Joan. Biotropica 28: 600-613.

Vandermeer, J. \& I. Granzow-de-la-Cerda. 2004. Height dynamics of the thinning canopy of a tropical rain forest: 14 years of succession in a post-hurricane forest in Nicaragua. Forest Ecol. Manag. 99: 125135 .

Vandermeer, J.H., D.H. Boucher, I. Granzow-de-la-Cerda \& I. Perfecto. 2001. Growth and development of the thinning canopy in a post-hurricane tropical rain forest in Nicaragua. Forest Ecol. Manag. 148: 221-242.

Vandermeer, J.H., I. Granzow-de-la-Cerda, D.H. Boucher, I. Perfecto \& J. Ruiz. 2000. Hurricane disturbance and tropical tree species diversity. Science 290: 788-791.

Vandermeer, J.H., N. Zamora, K. Yih \& D.H. Boucher. 1990. Regeneración inicial en una selva tropical en la Costa Caribeña de Nicaragua después del huracán Juana. Rev. Biol. Trop. 38: 347-359.

Wills, C., R. Cordit, R.B. Foster \& S.P. Hubbell. 1997. Strong density- and diversity- related effects help to maintain tree species diversity in a neotropical forest. Ecology 94: 1252-1257.

Yih, K., D.H. Boucher, J.H. Vandermeer \& N. Zamora. 1991. Recovery of the rainforest of southeastern Nicaragua after destruction by hurricane Joan. Biotropica 23: 106-113.

Zagt, R.J. \& M.J.A. Werner. 1998. Community structure and the demography of primary species in tropical rain forest, p. 193-219. In D.M. Newbery, H.H.T. Pins \& N.D. Brown (eds.). Dynamics of tropical communities. Blackwell Science, Oxford, England. 